\title{
A rare case of fatal meningoencephalitis with septic thromboembolism due to otitis media: a forensic case and review of literature
}

\author{
Isabella Aquila, ${ }^{1}$ Santo Gratteri, ${ }^{2}$ Matteo Antonio Sacco, ${ }^{1}$ Pietrantonio Ricci ${ }^{1}$
}

${ }^{1}$ Institute of Legale Medicine, University Magna Graecia of Catanzaro, Catanzaro, Italy ${ }^{2}$ AO MaterDomini Catanzaro, Catanzaro, Italy

\section{Correspondence to} Dr Isabella Aquila, isabella.aquila@hotmail.it

Accepted 15 June 2017
CrossMark

To cite: Aquila I, Gratteri $S$, Sacco MA, et al. BMJ Case Rep Published Online First: [please include Day Month Year]. doi:10.1136/bcr-2017 220594

\section{DESCRIPTION}

Meningitis is an inflammatory syndrome involving the meninges, and it manifests with headache and stiff neck. On the contrary, encephalitis refers to the inflammation of the brain parenchyma. The causative pathogens can be manifold though, except for immunocompromised patients; in literature, there are no cases of meningoencephalitis caused by bacteria usually present in the bowel.

We report the case of a 40-year-old man. Following an earache, the man went to the hospital. In anamnesis, the man reported a chronic otitis media for many years, and clinicians, noting auricular bleeding, advised local antibiotic treatment. The next day, he had fever, treated with paracetamol. After 3 days, following the worsening of the clinical condition, the man returned to the hospital where physicians detected temporal and spatial disorientation, neck stiffness and fever of $39.5^{\circ} \mathrm{C}$. Despite medical therapy, the man died after a few hours. An autopsy was performed. It showed an abscess on the right fronto-parietal lobe (figure 1) and, on the cerebellar vermis (figure 2), a thrombosis of the lateral sinus and a massive septic

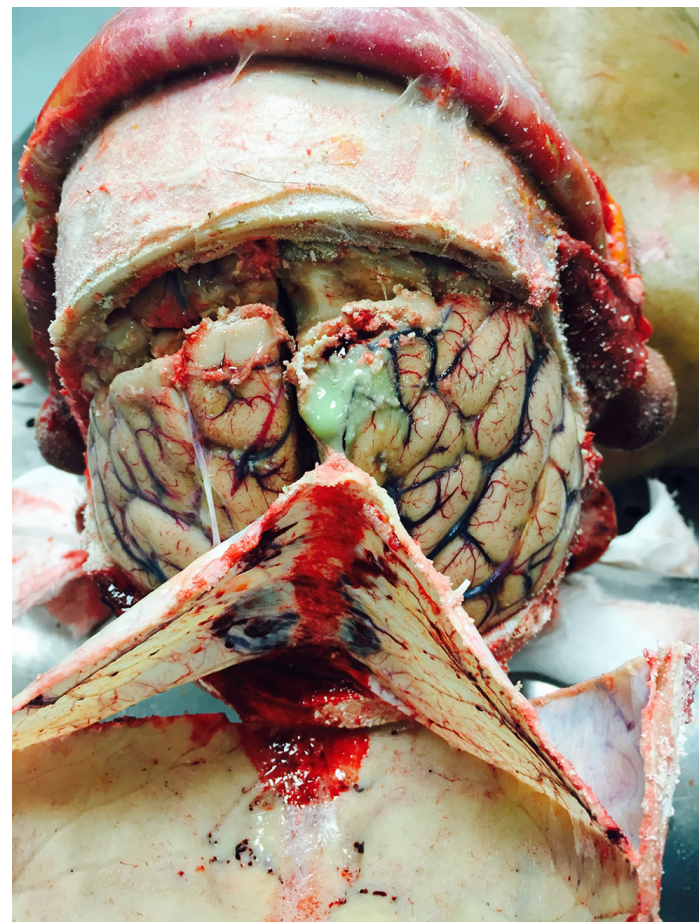

Figure 1 Brain abscess on the right fronto-parietal region. thromboembolism (figures 3 and 4) of pulmonary veins, the superior vena cava, aorta and right iliac vein. An histopathological and microbiological investigation was carried out. ${ }^{1}$ In particular, the microbiological investigation of the brain and the meninges (made with sterile swabs) showed the presence of Escherichia coli, Enterobacter cloacae complex, Acinetobacter baumannii and Candida albicans. The histopathological investigation after autopsy showed granulocyte infiltrate with presence of polymorphonucleates in fibrin agglomerates. During hospitalisation, the man have presented a marked neutrophilia with increase of lymphocytes and monocytes. The CT showed the presence of right cerebral air bubble with diffuse oedema and hyperdense area of the inner ear (figure 5).

Chronic otitis media may present extracranial and/or intracranial complications. The most common extracranial diseases include facial paralysis, subperiosteal abscess, mastoiditis and labyrinthitis. The intracranial complications are meningitis, brain abscess, lateral sinus thrombosis, extradural abscess, hydrocephalus and encephalitis. Many studies have shown that the high incidence of otitis media, the inaccuracies in the diagnosis and

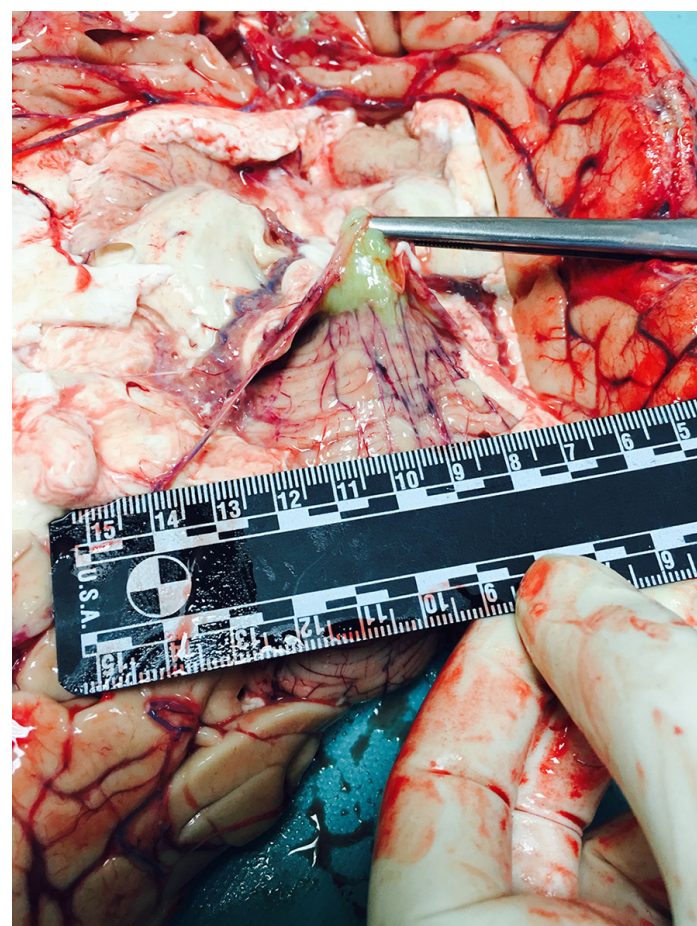

Figure 2 Abscess on the cerebellar vermis. 


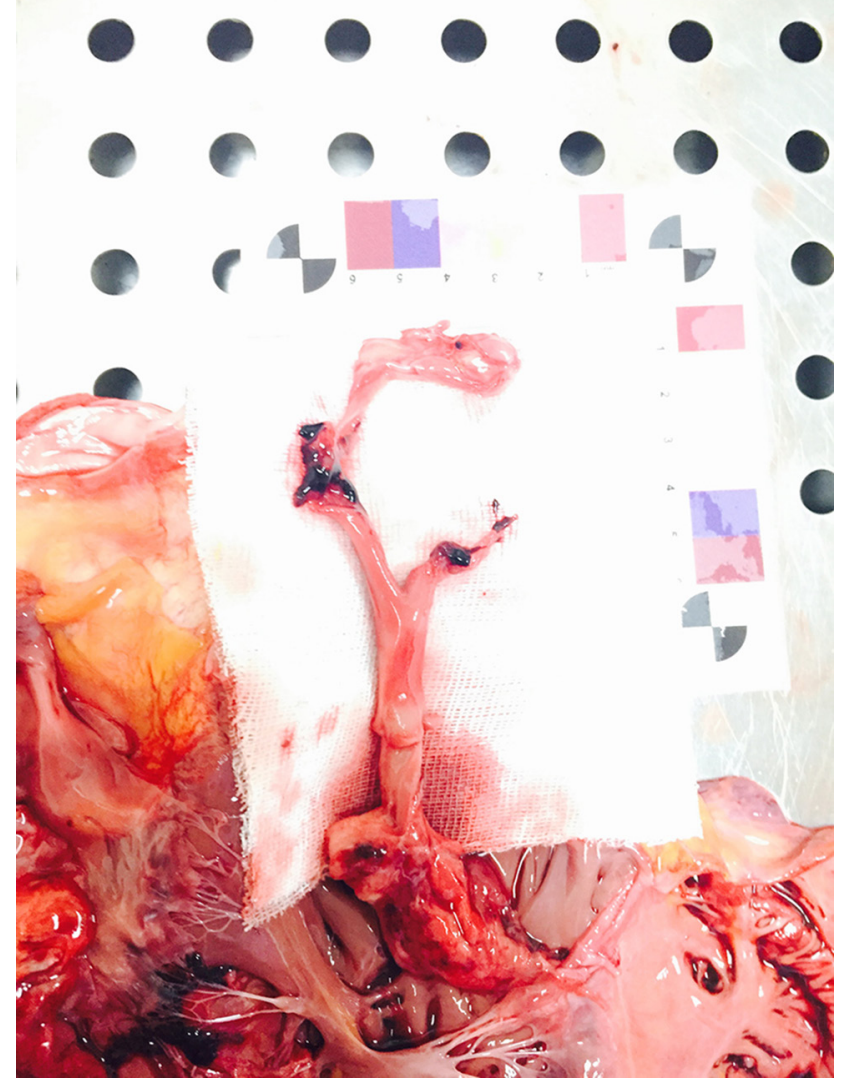

Figure 3 Finding of pulmonary thromboembolism.

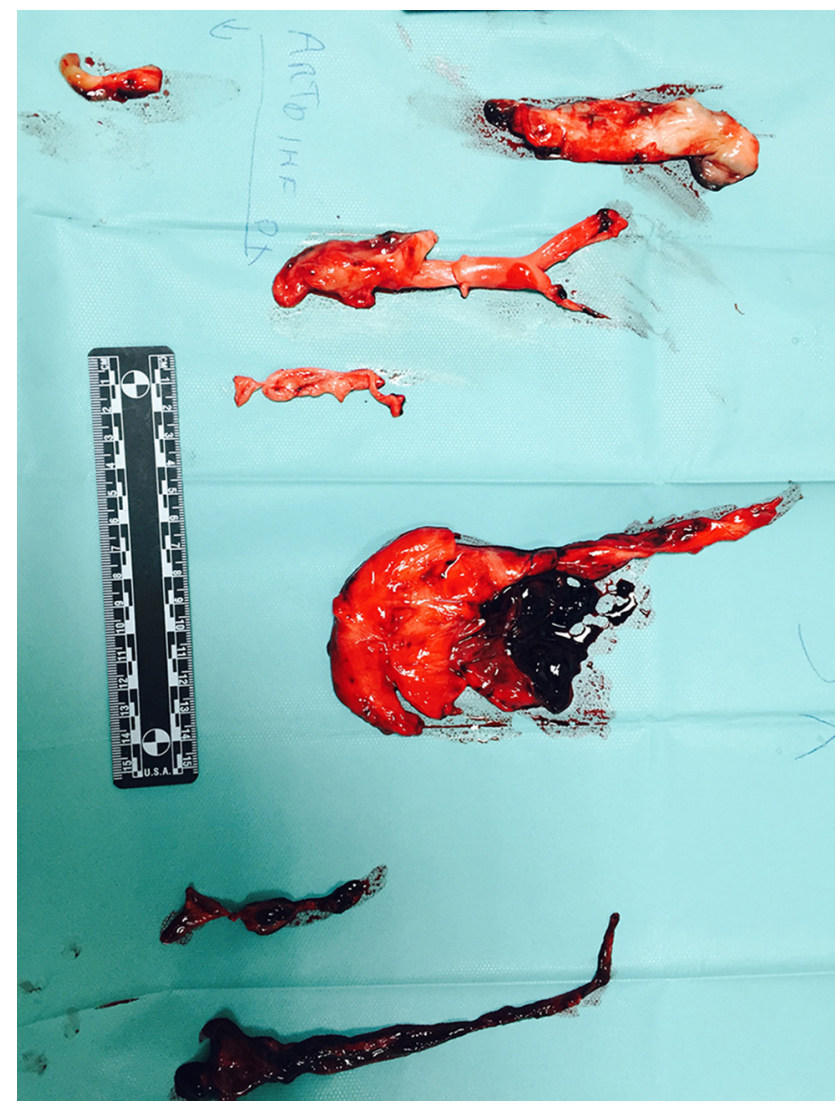

Figure 4 Septic thromboemboli found in the inferior vena cava, the iliac vessels and the heart.

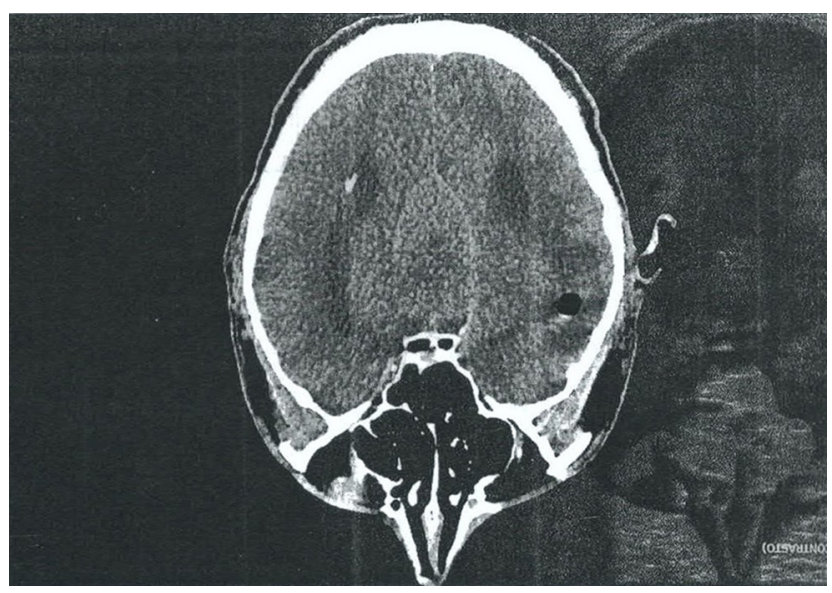

Figure 5 CT scan showed right cerebral air bubble with diffuse oedema and hyperdense area of the inner ear.

\section{Learning points}

- Tympanic perforation is a risk factor for migration of external pathogens within the meninges.

- It is an erroneous but widespread belief that the intracranial complications of acute and chronic otitis media belong to the past or they are attributable only to the developing countries.

- This case has shown that, despite the improvements in antibiotic treatment, the problem of morbidity and mortality remains high.

the possibility of life-threatening sequelae make this disease a major public health problem. As such, the physician should have a high index of suspicion during the medical examination of a patient with otitis media. ${ }^{2}$

Although it is often problematic to determine the path of bacterial infection from the middle ear to the meninges in the presence of middle ear otitis, possible paths are (1) via the blood, (2) direct spread or invasion (3) through the bone defect and (4) through the cochlear aqueduct.

Thus, if there is an external invasion, it is easy that the causative bacteria could be different with respect to the microorganisms usually responsible for the meningitis. The purpose of the study is to emphasise the role of diagnosis and treatment of otitis media in prevention of fatal events, in particular in the presence of tympanic perforation. The case has confirmed that, as a result of bathing diving in contaminated water, the entrance through the right ear allowed the access of bacteria usually present in the faeces.

Contributors IA is the forensic pathologist and the official responsible of the case. She performed the autopsy, conceived the idea and managed the whole realisation of the paper. SG has contributed through the realisation of microbiological analysis and the interpretation of the data. MAS has contributed through the writing of the case report. PR managed with her the realisation of the work.

\section{Competing interests None declared.}

Patient consent We certify that this study analyzes a patient who died. For this reason it was not possible to obtain consent form. Dr. Aquila I. (Corresponding author) has had an assignment by the prosecutor to carry out an autopsy and for this reason the authors asked permission to court in order to use the case and its scientific data.

Provenance and peer review Not commissioned; externally peer reviewed.

(C) BMJ Publishing Group Ltd (unless otherwise stated in the text of the article) . All rights reserved. No commercial use is permitted unless otherwise expressly granted. 


\section{REFERENCES}

1 Aquila I, Di Nunzio C, Paciello 0, et al. An unusual pedestrian road trauma: from forensic pathology to forensic veterinary medicine. Forensic Sci Int 2014;234:e1-4.
2 Wu JF, Jin Z, Yang JM, et al. Extracranial and intracranial complications of otitis media: 22-year clinical experience and analysis. Acta Otolaryngol 2012;132:261-5.

3 Penido NO, Borin A, Iha LC, et al. Intracranial complications of otitis media: 15 years of experience in 33 patients. Otolaryngol Head Neck Surg 2005;132:37-42.

Copyright 2017 BMJ Publishing Group. All rights reserved. For permission to reuse any of this content visit

http://group.bmj.com/group/rights-licensing/permissions.

BMJ Case Report Fellows may re-use this article for personal use and teaching without any further permission.

Become a Fellow of BMJ Case Reports today and you can:

- Submit as many cases as you like

- Enjoy fast sympathetic peer review and rapid publication of accepted articles

- Access all the published articles

- Re-use any of the published material for personal use and teaching without further permission

For information on Institutional Fellowships contact consortiasales@bmjgroup.com

Visit casereports.bmj.com for more articles like this and to become a Fellow 